\title{
6 Dynamics between the state, mining companies, and indigenous peoples in Peru
}

\author{
José Bayardo Chata Pacoricona ${ }^{1}$
}

The business sector is adamant: mining is an essential activity for the future of Peru. The impact of mining on sectors like metalworking, agriculture, livestock, fishing, information technology, and communications purportedly demonstrates the importance of this sector for the country's growth (see Benavides Ganoza 2018). However, at the community level, these positive impacts are rarely felt, and frequently communities' dissatisfaction about being shut out from the development of a mining project leads to social protests and other forms of resistance that are ripe for violence and conflict.

A good example is Tía María, an open-pit copper mine in the Cocachacra district of Peru's Islay Province that has led to a decade of conflict with the local community. The government has strongly supported this project despite strong opposition from farmers, whose access to groundwater is threatened by the preferential water access given to the mining company. In response to social conflict, the company eventually reversed course and decided to use seawater, but the water supply remains at risk of contamination. Despite this, the government has persisted in its position that the project is vital to national economic growth.

The main actors in all socio-environmental conflicts around mining, like Tía María, are the same. First, we find the people, whose rights are overlooked as they are forced into a damaging economic activity alien to the cultures and livelihoods to which they are accustomed. Secondly, there is the private company, which "in compliance" with all the requirements imposed by national legislation for undertaking extractive activities, struggles to make effective its claim to extract minerals from the subsoil. And finally, there is the state, with its pro-extractive and proprivate investment policies, regulations, and practices that do not align with its obligations to defend its citizens, guarantee human rights, and promote general well-being founded on justice (see Political Constitution of Peru, art. 44).

Our organization, Derechos Humanos y Medio Ambiente-Puno, Peru (DHUMA), pressures the government to meet its obligations by pushing back against deceptive narratives about positive impacts of mining and

DOI: $10.4324 / 9781003094272-6$ 
helping communities resist mining development through legal processes that they are typically unaware of or not capable of utilizing. DHUMA was founded in 1988 as the Vicariate of Solidarity within the Catholic Prelature of Juli. The impetus was the increasing political violence faced by indigenous communities during the 1980s. Several religious congregations, lay parish workers, and ecclesial leadership coordinated to found the Vicariate, and in 2008 it became an independent civil society organization. DHUMA has maintained its Catholic identity and its mission remains rooted in the principles of the gospel and Catholic social teaching. And its work has remained focused on helping the indigenous communities of the Puno region.

This chapter describes the fraught dynamics between communities, companies, and the state in the context of mining, and demonstrates how we attempt to defend those communities before these situations lead to violence, dispossession, ecological destruction, and human rights abuses.

\section{The state and the corporations}

The bonds between private companies and the state are extremely worrying. The dealings between private investment and the government are principally based on lobbying agendas, hidden negotiations, and corruption. For example, the Lava Jato corruption case is one of the largest known to date, involving private companies and governments in various countries across Latin America where infrastructure megaprojects have been carried out on the back of billions of dollars in bribes. According to a report from Oxfam:

The analysis of these megaprojects allows us to understand the way in which laws are made, influencing what is called 'tailored legislation,' legislation tailored to certain interests in how it is created and applied, where governments and officials frequently ignore, especially in cases of public works, the spirit of the laws and their necessary ethical basis, attending instead to the mere fulfillment of formalities to give a legal varnish to projects that have numerous problems. (Durand 2018, 17)

This appearance of legality and claims that the state is fulfilling its duty to promote general well-being masks the real goal behind each project or private investment: the self-interest of politicians and public officials.

Ordinary citizens are bystanders to these million-dollar scandals and are left wondering if the whole state machinery moves only to the rhythm of monetary kickbacks and whether all the laws and policies of the state work like this. In the same way that there is empirical certainty about institutionalized corruption in the Peruvian judicial system (IDL Reporteros 2018), illegal agreements made between private companies and the Peruvian state are being revealed as they unravel over time. 


\section{An emblematic case: the Aymarazo}

On November 28, 2007, Supreme Decree 083-2007-EM was issued, declaring private investment in mining a public necessity. It enabled the Peruvian subsidiariy of Canada's Bear Creek Mining Corporation to acquire concessions and rights over mines and complementary resources for development of production activities inside a fifty-kilometer zone along the border with Bolivia. This development, the Santa Ana mining project, is located in the Puno region on indigenous Aymara territory. This decree was the starting point for the socio-environmental conflict known as the Aymarazo.

To deliver the concessions that make up the Santa Ana project, an exception had to be used. Constitutionally, foreigners cannot acquire land rights of any kind within fifty kilometers of the border (Political Constitution of Peru, art. 71). Upon signing the supreme decree, this article of the constitution was dismissed on the grounds of "public necessity." In issuing this decree, the state sought to substantiate that granting mining rights to Bear Creek would, in fact, have a beneficial impact on the well-being of the general community. In addition, it was assumed that development of this border zone would bring improved living standards for the inhabitants in the area-something that, unfortunately, generally does not happen in these situations. "Public necessity" should be about needed works that are truly public, that benefit the broader community and not just private business interests. The "public necessity" designation is, for example, for infrastructure works like the construction of roads, hospitals, or dams; the decontamination of lakes or rivers; or the extension of electricity, telecommunication, or drinking water networks (Ruiz Molleda 2011). As such, we question what this business activity has to do with the public interest.

\section{Agreements between the National Police of Peru and mining companies}

In 2019, three institutions looked closely into the agreements that have been signed between the National Police of Peru and mining companies nationwide. The examination covered 138 agreements signed between 1995 and 2018. In the report, these institutions discovered that 109 of the agreements were signed before 2017, an average of nine per year. Then the count accelerated to 29 between 2017 and 2018. On review, it seems that 29 agreements in force at the time were due to expire between 2019 and 2022. What is striking is that most of the existing agreements apply to projects located in regions where there has been social unrest and the projects have been questioned by local communities (EarthRights International, Instituto de Defensa Legal, and Coordinadora Nacional de Derechos Humanos International 2019). 
The content of these agreements deserves special study since they differ from each other in their commitments. There are agreements whose aims include the "detection and neutralization of risks," without establishing any exact definition, leaving the determination open to interpretation by the contracted police officers and the corporate representatives. "Risk" could be read as any action, such as a demonstration or protest, carried out by a person or group defending interests or opinions that differ from those of the corporations concerned. Other agreements have clauses guaranteeing "normal development," and controlling "acts of vandalism and sabotage or terrorism." These ambiguous and indeterminate terms can be interpreted in a discretionary way by interested parties, favoring private interests to the detriment of the individual and collective rights of the local population (EarthRights International, Instituto de Defensa Legal, and Coordinadora Nacional de Derechos Humanos International 2019).

As a result of these agreements between the National Police of Peru and extractive corporations, the police have been providing extra services biased toward corporate interests and discriminating against communities in exchange for economic compensation. In this way, police officers have become private guards for corporations, undermining their function as public servants who receive their salaries from taxpayers. In practice, we are faced with the privatization of domestic order and the public function of the police force (Ruiz Molleda and Salvador n.d.).

This situation makes clear an obvious conflict of interest for the National Police. It is impossible for its forces to distinguish public from corporate interest. This scenario encourages criminalization of social protest and abusive use of police force. Ultimately, the damage is borne by indigenous communities and peoples that live in the immediate vicinity of mining operations (Leyva 2018,39). The crisis worsens in situations of social conflict, where the partiality of the National Police can result, and has resulted, in clear human rights violations. This is demonstrated by the case of the Las Bambas copper mine in Apurímac, where, since 2015, criminalization of the rural population has resulted in four protestors' deaths. This police "function" is obviously not protecting public order but rather the interests of corporations; it is not preserving peace, but is aggravating conflict (EarthRights International, Instituto de Defensa Legal, and Coordinadora Nacional de Derechos Humanos International 2019).

\section{The state and indigenous peoples}

\section{The idea of development from two perspectives}

The Aymarazo case is an example of a clash of perspectives on development. By declaring the mine a public necessity, and in granting mining concessions that skirted constitutional standards, the state asserted that the mining project would contribute to economic development and to the 
improvement of the quality of life of the rural communities involved. The conviction of the state remains that mining should be at the center of the national economy. ${ }^{2}$ As such, it places the entire state apparatus at the service of its mining portfolio, without considering the right of communities or ancestral owners to refuse mining in their lands and territories. Whether or not the government is acting in good faith, the reality is that this vision of progress differs greatly from the ancestral perspective of development that communities hold. That view is rooted in a sacred understanding that cannot be adequately captured in economic or patrimonial reckonings alone, and that resonates with Catholic senses of care for creation and integral ecology (Francis 2015, ch. 4). The result of these opposing positions is socio-environmental conflict. This pattern is repeated in the majority of such conflicts in the country. Despite the omnipresence of these dynamics, it appears there is no real solution proposed that could meaningfully prevent future conflicts. In June 2019, the Ombudsman's Office of Peru, Office for the Prevention of Social Conflicts and Governance (2019) reported four new social conflicts in the prior month, raising the national total to 178: 130 active and 48 latent. Of the 178, 117 were of a socio-environmental nature, $62.4 \%$ ( 73 cases) of which were related to mining activity and $16.2 \%$ (19 cases) linked to hydrocarbon activity. This data shows the level of resistance to mining and hydrocarbon activities as expressed through social protest.

This final point has to do with the right of the people to selfdetermination. With its pro-extractivist vision, the state arbitrarily wields the power to decide what is beneficial for indigenous peoples (IPs), completely distorting this right. Article 7 of Convention 169 of the International Labour Organization indicates that IPs have the right to decide their own priorities regarding economic development. In Catholic social teaching, the right of self-determination is grounded particularly in freedom and the right of individuals and peoples to participate in shaping their futures. Straightforwardly, Pope Francis $(2020, \mathbb{\$} 14)$ has written that business enterprises that violate the self-determination of IPs are crimes. Respect for self-determination is necessary for integral human development, defined not only in economic terms, but also in terms of protecting communal identity and enabling all peoples to contribute to the common good (Powers 2019, 60).

In 2019, Peru's Ministry of Energy and Mines released "Vision of Mining in Peru to 2030," outlining a path for making mining a central pillar of the national economy. ${ }^{3}$ The dependence of our economy on mining is worrying, and is reinforced through norms and state policies that reaffirm the extractive-oriented interests and priorities of corporations and the government. The rapid change in national regulations and state policies is clearly at the expense of the people who already live in mining areas, and IPs who are at risk of having their lands lost to mining. These changes seek to eliminate, in a way that is presented as beneficial, the guarantees of 


\section{José Bayardo Chata Pacoricona}

communities' rights to land and territory, an adequate and balanced environment, and participation, prior consultation, and fundamental selfdetermination about their development. All of this goes against the nation's constitution, international human rights norms, and principles of Catholic social thought and integral human development.

\section{Policies and governance favoring mining companies over communities}

Law 30230 places more than eight thousand rural and indigenous communities in a situation of vulnerability. This law allows the state, through "special procedures," to hand over land to investment projects, in the location and amount that the investor requires, ignoring the property rights of legitimate owners. For mining, these owners are often IPs. These special procedures affect all properties, be they private or state lands, whether they are backed by deeds or any other documentation. No exceptions of any kind apply.

One of the legislative decrees most responsible for weakening communal property rights and the autonomy of rural communities has been D.Leg. 1333, which is known as the "law of dispossession." This law, which builds upon Law 30230, was repealed in Congress, but it is kept in force by executive action. The regulation allows the state more control over communal property and territory so as to facilitate granting mining concessions to private companies. This standard is complemented by D.Leg. 1320, which extends the ownership of mining concessions to thirty years, even for concession holders who do not pay their annual right of validity fee to the state (Red Muqui n.d.).

Laws and policies prioritizing mining by weakening environmental regulation have also been harmful to IPs. The loosening of environmental protection standards is based on modifications to the government's environmental quality standards for air and soil, and the maximum permissible limits of toxic elements. These modifications give wide latitude for companies to pollute while offering virtual impunity and preventing compensation for those communities harmed by pollution. Among these rules is Supreme Decree 003-2017. This decree weakens standards for sulfur dioxide and other toxic materials generated by extraction activities. Chief Resolution 056-2018-ANA on the Classification of Continental Water Bodies is another example. It was meant to designate some bodies of water as more fragile and thus due stricter protection. But technical clarification on the classification was not given, allowing mining companies to more easily pollute. Other regulations have been issued that favor the privatization of water (D.Leg. 1280), facilitating its privileged use for mining activity and not for citizens' collectives or consumption by the general population. Legislative Decree 1285, issued at the end of 2016, modifies article 79 of Law No. 29338, the Law of Water Resources. These norms establish 
provisions for a progressive permissiveness towards oil spills and mining tailings and make environmental management mechanisms more malleable, during and after extractive activity. In short, these provisions facilitate pollution with impunity (Red Muqui n.d.).

Another tactic the government has used to harm IPs and other communities is declaring states of emergency. The state has used this tactic to restrict fundamental rights and allow police or military intervention without having to prove the existence of a serious breach of public order, as required by article 137 of the Peruvian constitution. This is a blatant abuse of state power outside the constitutional framework. For example, a state of emergency was imposed in the districts tied to the Las Bambas mining project that included the entire Apurimac-Cusco-Arequipa Road Corridor, which is 482 square kilometers in area and extends 500 meters on each side of the highway. In some places, states of emergency have been declared preventively, restricting such fundamental rights as individual freedom, freedom of assembly and movement, and inviolability of the home. In some cases, citizens have been prevented from having public gatherings, even ones that are not of a political nature (Ruiz Molleda et al. 2019).

\section{Consultation, social protest, and peaceful remediation}

Formal processes have always presented an obstacle for indigenous peoples. Mining concessions are unilaterally granted by the Mining and Metallurgical Geological Institute (INGEMMET) at the request of an interested corporation. ${ }^{4}$ Consequently, indigenous communities based at mineral-rich sites live in constant fear, under the permanent threat that hangs over their land. According to law, the mining concession holder will not be able to use the land unless he or she has an official agreement with the land owner or has been granted a mining easement. However, if no agreement has been reached, the holder of the mining concession may request an easement from the General Mining Directorate of the Ministry of Energy and Mines. In other words, even in the face of opposition from the community, the legal framework favors the concession holder. A concession holder can press ahead with mining exploration and exploitation by seeking an easement, regardless of whether the community opposes the project.

Convention 169 of the International Labour Organization (1989), which grants protections to IPs, was ratified by Peru in 1994. The struggle to uphold Convention 169 is led by the same people it is meant to protect, with accompaniment from us at DHUMA, but without support from the state. Although progress is being made in short steps for the rights contained in this rule to be recognized in practice, the state continues by various means to undermine efforts to enforce it. For example, the peasant communities of Chila Chambilla and Chila Pucara were the first Aymara indigenous communities to initiate a judicial process against the Peruvian state for the omission of the right to prior consultation and the violation 


\section{José Bayardo Chata Pacoricona}

of the right to territory in the delivery of mining concessions to a private company. The magistrates in charge of the case stated that Convention 169 does not protect them because they were unable to provide sufficient proof that they belong to an indigenous people, denying them their cultural identity.

Article 6.1.a of Convention 169 makes clear that consultation with IPs about use of their land needs to happen in the earliest stages of any possible project: "governments should ... consult the peoples concerned, through appropriate procedures and in particular through their representative institutions, whenever legislative or administrative measures are expected to directly affect them." This standard has been developed by article 4.a of the Law on Consultation (Law 29785), and a similar concept, called the Constitutional Principle of Prior Implementation of the Consultation Process, has been proposed by Peru's Constitutional Court. This principle mandates that "consultation be carried out prior to any decision. An essential idea behind the inclusion of indigenous peoples in the discussion of the project of the administrative or legislative measure is that they have an opportunity to raise their cultural perspectives, so that they may be taken into account" (Constitutional Tribunal of Peru 2010, legal basis 36).

But the procedure for granting mining concessions in Peru is absolutely incompatible with these legal norms (see International Labour Organization 1989, art. 13-15; Political Constitution of Peru, art. 88). The Aymarazo conflict arose when rural communities in Puno learned that INGEMMET had delivered mining concessions on about $60 \%$ of the territory of Puno, behind the backs of communities and without their prior consultation. This follows a typical pattern where communities often become aware of concessions only after the deadline to file their opposition has passed. Prior consultation can be used to channel misgivings and avoid social protests by communities, but it is frequently evaded or enacted in only superficial ways.

The one requirement to be granted a mining concession is that the potential concession holder publish a single notice in two newspapers, one of national and the other of regional scope. Five key barriers prevent rural communities from being able to access such notices: (1) notices are published in newspapers that only circulate in urban areas and not in rural areas where IPs live; (2) they are published in Spanish and not the native languages of IPs; (3) the only way to access these notices is to buy the newspapers, which are expensive for the economically vulnerable IPs; (4) Andean cultures are mostly oral, which prevents indigenous communities from understanding the content of the ads; and (5) complete information relating to the mining concessions and their respective administrative files are logged in a database which can only be accessed through a computer with an internet connection, which many indigenous communities do not have. ${ }^{5}$ And in the event that a notice does reach the communities, it does not specify the name of the communities to be affected, or include maps of the concessions. This all means that IPs are being systematically excluded 
from legal processes for determining the status of their lands. However, the General Law of Administrative Procedures is very clear about what ought to happen: "If, during the filing of a procedure, the existence comes to light of non-appearing third parties whose legitimate rights or interests may be affected by the resolution to be issued, said procedure must be communicated to them by means of a summons delivered to their known address, without interrupting proceedings" (Presidency of the Council of Ministers of Peru 2001, art. 60.1). This legal provision has not been complied with in any mining administrative procedure.

Faced with this lack of meaningful prior consultation, and the frequent failure of the state to take into account the livelihoods and cultures of native peoples, archaeological remains, ${ }^{6}$ or areas destined for agriculture expansion ${ }^{7}$ when granting concessions for mining, communities choose to exercise their right to social protest. This leads to conflict and opens the way for violence, especially in light of the way social protest has been criminalized.

The criminalization of protest is a multidimensional phenomenon that includes actions and speech aimed at repressing and delegitimizing political dissent. Acts of repression may include assassinations, executions, disappearances, attacks, threats, harassment, spying, and persecution via criminal proceedings, and they may be against an individual or a collective. Criminalizing discourse discredits protesters as lawbreakers, radicals, and, in the most extreme cases, terrorists. This is the ideological justification that favors the state against social protest (Saldaña and Portocarrero 2017).

Social protest is distorted by the state and treated as a criminal offense to be punished. A clear example of the use of law to prosecute protest leaders is article 200 of the Peruvian Criminal Code, third paragraph:

The one who, through violence or threat, occupies premises, hinders communication channels or prevents the free transit of citizens or disrupts the normal functioning of public services or the execution of legally authorized works in order to obtain any benefit or advantage from the authorities of an undue economic or other advantage of any other nature ... The penalty shall be not less than fifteen or greater than twenty-five years [of imprisonment] and disqualification pursuant to numerals 4 and 6 of article 36, if the violence or threat is committed. (Ministry of Justice and Human Rights of Peru 2016)

Following this logic, the main Aymara spokespeople saw themselves criminally denounced for crimes such as riots, aggravated extortion, and obstruction of public services following the Aymarazo protest. Such criminal definitions place a chilling pall over any act of protest. In joint interinstitutional cooperation, the Institute of Legal Defense and the Bar 
Association of Puno have sought a declaration of unconstitutionality of this article so that it ceases to have criminalizing effects.

In light of these realities, our organization attempts to offer resources for communities to use legal mechanisms as a means of peacefully attaining justice and realizing their own visions of development. We see this alternative as urgent, recognizing that protest can result in injury, death, detention, and criminal charges. In that same vein, human rights organizations decided to present a set of lawsuits before the judiciary and the Constitutional Court against different state actors for their failure to comply with consultation requirements. Such claims form part of what we call "strategic litigation." On top of obtaining favorable sentences for individual cases, we seek to put discussions regarding the situation of rural communities in extractive contexts high on the legislative agenda. Cases where consultation was omitted for mining activity in Puno include the Quechua communities of Atuncolla, San José de Llungo, San José Principio, and Arboleda, which was a pioneer in demanding consultation at the national level, and the Aymara communities of Jatucachi, Chila Chambilla, and Chila Pucara.

\section{Conclusion}

When we examine the dynamics between the state, companies, and indigenous communities, it appears that IPs have no alliances other than some select groups dedicated to advocating for them. Through corruption, legal and procedural complexity and obfuscation, and criminalization of protest, IPs cease to be protagonists in the stories of their own lands. They are beset by grave power imbalances and other disadvantages that prevent them from being able to use legal channels before mining projects move past critical points of development. And when they try to respond after the fact, they are frequently met by violence and repression.

The social doctrine of the Catholic Church teaches us to take a political, social, and religious stance in favor of the people, especially the most vulnerable. This doctrine encompasses all aspects of human dignity, and its fulfillment is central to the Christian vocation. At DHUMA, we focus on the mandate in Laudato Si' to hear the cry of the earth as well as the cry of the poor. From our time as part of the Prelature of Juli through our work today as an independent organization, we continue to dedicate ourselves to the defense of life and Mother Earth, and the accompaniment of the children of God. In Puno, that mostly includes dealing with the violation of the rights of IPs in relation to mining. The long history of suffering of native peoples was aggravated greatly during the political violence in Peru from 1980 to 2000, and now that suffering includes violence against nature and lands which IPs hold sacred and on which they depend for their well-being.

Because of this reality and our commitment to Catholic social teaching, we help indigenous communities know their rights, understand mining 
development projects and processes, and navigate legal channels to redress problems. Such activities are an important element of peacebuilding in Peru and other countries in the Global South facing similar challenges, whether they involve IPs or other vulnerable and marginalized communities. DHUMA, rooted in a Catholic legacy, will continue to advance and deepen such work with the communities of Puno, Peru.

\section{Notes}

1 Translated from Spanish by Thomas McDonagh.

2 The Directorate General for Promotion of Sustainable Mining presented a 2020 update of the Mine Construction Project Portfolio consisting of 46 projects and investments amounting to US\$56.158 million. These investments include projects for the construction of new mines, expansion of existing ones, and the reuse of tailings (Ministry of Energy and Mines of Peru 2020).

3 DHUMA is a member of Red Muqui, a national platform of institutions that engages in advocacy to support rural communities and defend the environment in the context of mining. Red Muqui refused to endorse this statement, despite its attempts to present sustainable and inclusive models of mining development.

4 INGEMMET is a decentralized technical public body that forms part of the Ministry of Energy and Mines. INGEMMET's work is aimed at obtaining, administering, and efficiently disseminating geoscientific information and data related to basic geology, subsoil resources, and geological risks. It is also responsible for conducting the Ordinary Mining Procedure, including receiving petitions, granting and revoking mining concessions, systematizing georeferenced information through the National Mining Cadastre, as well as the administration and distribution of permits and penalties.

5 Despite this, curiously, INGEMMET has been awarded prizes by the state. In 2012, it achieved first place in its category, Transparency and Access to Information, based on the use of information systems called GEOCATMIN (Geological Cadastral Mining System) and SIDEMCAT (Mining Rights and Cadastre System) and on its role as a disseminator of the geological and cadastral information that the institution manages. Also, at the 2015 conference "Good Practices in Geo-Information Management" organized by the National Office of Electronic Government and Information Technology, INGEMMET won an award in the category of Metadata Management.

6 In 2011, INGEMMET delivered mining concessions in grids that covered the pre-Inca archaeological complex of Sillustani, whose main attraction are its chullpas, funeral towers that formed part of the architectural expression of the Kolla culture, located in the Atuncolla district, Puno province and region.

7 Article 14 of the General Mining Law indicates that: “... no non-metallic concessions or extensions of non-metallic concessions may be established, on intangible agricultural areas, or on rustic lands for agricultural use, without considering between these and last to natural pastures" (Ministry of Energy and Mines of Peru 1992). However, the Ministry of Agriculture and Irrigation does not have official data on all the territories designated for agriculture, and many communities have extended agricultural activity beyond known territories. And in the case of mining concessions of a metallic nature, no limit is established, whether it is for agricultural purposes or not. 


\section{References}

Benavides Ganoza, Roque. 2018. La Minería Responsable y sus Aportes al Desarrollo del Perú. 3rd ed. Compañía de Minas Buenaventura. https://www.buenaventura. com/assets/mineria-responsable/\# $\mathrm{p}=1$.

Constitutional Tribunal of Peru. 2010. Sentence of the Constitutional Tribunal, Exp. No 00022-2009-PI/TC. https://www.tc.gob.pe/jurisprudencia/2010/000222009-AI.html.

Durand, Francisco. 2018. Odebrecht-La empresa que captura gobiernos. Lima: Pontificia Universidad Católica del Perú; Oxfam Peru. https://oi-files-cng-prod.s3. amazonaws.com/peru.oxfam.org/s3fs-public/file_attachments/Odebrecht-La-empresa-que-capturaba-gobiernos.pdf.

EarthRights International, Instituto de Defensa Legal, and Coordinadora Nacional de Derechos Humanos International. 2019. Informe: Convenios entre la Policía Nacional y las empresas extractivas en el Perú: Análisis de las relaciones que permiten la violación de los derechos humanos y quiebran los principios del Estado democrático de Derecho. https://www.idl.org.pe/portfolio/conveniosentre-la-policia-nacional-y-las-empresas-extractivas-en-el-peru.

Francis. 2015. Laudato Si'. http://www.vatican.va/content/francesco/en/encyclicals/ documents/papa-francesco_20150524_enciclica-laudato-si.html.

Francis. 2020. Querida Amazonia. http://www.vatican.va/content/francesco/en/ apost_exhortations/documents/papa-francesco_esortazione-ap_20200202_ querida-amazonia.html.

IDL Reporteros. 2018. “Corte y corrupcíon.” Updated July 12, 2018. https:// www.idl-reporteros.pe/corte-y-corrupcion/.

International Labour Organization. 1989. Indigenous and Tribal Peoples' Convention. C169. https://www.ilo.org/dyn/normlex/en/f?p=NORMLEXPUB:12100:0::NO:: P12100_ILO_CODE:C169.

Leyva, Ana. 2018. Consúltame de verdad. Aproximación a un balance sobre consulta previa en el Perú en los sectores minero e hidrocarburífero. Lima: Oxfam, CooperAcción. http://cooperaccion.org.pe/wp-content/uploads/2018/ 07/Consultame-de-verdad.pdf.

Ministry of Energy and Mines of Peru. 1992. General Mining Law (Supreme Decree $\mathrm{N}^{\mathrm{o}}$ 014-92-EM). http://www.minem.gob.pe/minem/archivos/file/Mineria/ LEGISLACION/TUO\%20.pdf.

Ministry of Energy and Mines of Peru. 2019. "Visión de la Minería en el Perú al 2030." http://www.minem.gob.pe/_detalle.php?idSector=1\&idTitular=9757\& idMenu=sub149\&idCateg=1884.

Ministry of Energy and Mines of Peru. 2020. Cartera De Proyectos De Construcción De Mina. http://www.minem.gob.pe/minem/archivos/file/Mineria/ INVERSION/2020/CPM2020(1).pdf.

Ministry of Justice and Human Rights of Peru. 2016. Penal Code (Legislative Decree $\mathrm{N}^{\mathrm{o}}$ 635). http://spij.minjus.gob.pe/content/publicaciones_oficiales/img/ CODIGOPENAL.pdf.

Ombudsman's Office of Peru, Office for the Prevention of Social Conflicts and Governance. 2019. Reporte de Conflictos Sociales $N^{\circ} 184$. https:// www.defensoria.gob.pe/wp-content/uploads/2019/07/Conflictos-Sociales-N \% C2\%B0-184-Junio-2019.pdf. 
Political Constitution of Peru. http:/www.congreso.gob.pe/Docs/files/constitucion/ constitucion2019/index.html.

Powers, Gerard. 2019. "Toward a Catholic Ethic of Self-Determination." In Theology, Conflict, and Peacebuilding, edited by Daniel Franklin Pilario, 39-74. Quezon City, Philippines: St. Vincent School of Theology. https:// www.svst.edu.ph/publication-review/603f3c455c60e245\#.

Presidency of the Council of Ministers of Peru. 2001. Law of General Administrative Procedures. Law N $N^{\circ}$ 27444. http:/www.pcm.gob.pe/wp-content/uploads/2013/09/ Ley-de-Procedimiento-Administrativo-de-PersonalLey27444.pdf.

Red Muqui. n.d. "Normas y políticas públicas que afectan derechos fundamentales, colectivos y ambientales 2016-2018.” Accessed April 13, 2021. https://muqui.org/ wp-content/uploads/2019/11/Normas-y-politicas-publicas-2016-2018-IMAGENES-2.pdf.

Ruiz Molleda, Juan Carlos. 2011. “Análisis jurídico de las normas legales expedidas por el gobierno en el marco de las negociaciones con las comunidades campesinas de Puno.” Institut de Defensa Legal - Justicia Viva, Working Paper No. 53.

Ruiz Molleda, Juan Carlos, and Álvaro Másquez Salvador. n.d. "Informe juridico: la privatización de la seguridad ciudadana: La inconstitucionalidad de los contratos de seguridad privada entre empresas mineras y la Policía Nacional del Perú.” Justicia Viva. Accessed April13, 2021. http://www.justiciaviva.org.pe/ new/wp-content/uploads/2018/05/Informe-Jur\%C3\%ADdico-sobre-la-privatizaci\%C3\%B3n-del-orden-interno.-Versi\%C3\%B3n-final-16-09-2015.pdf.

Ruiz Molleda, Juan Carlos, Rocío Meza Suarez, Marisa Quispe Mamani, Álvaro Másquez Salvador, and Isaac Peña Lobato. 2019. “¿En qué va el litigio constitucional contra la criminalización de la protesta?” Instituto de Defensa Legal. June 18, 2019. https://idl.org.pe/en-que-va-el-litigio-constitucional-contra-la-criminalizacion-de-laprotesta/.

Saldaña, José, and Jorge Portocarrero. 2017. "La violencia de las leyes: el uso de la fuerza y la criminalización de protestas socioambientales en el Perú." Revista de la Facultad de derechos de la Pontificia universidad Católica del Perú 79: 311-352. http://revistas.pucp.edu.pe/index.php/derechopucp/article/ view/19329/19456. 